\title{
Effect of Additives on Lithium Doped Magnesium Oxide Catalysts Used in the Oxidative Coupling of Methane
}

\author{
S.J. KORF*, J.A. ROOS, L.J. VELTMAN, J.G. VAN OMMEN and J.R.H. ROSS \\ Faculty of Chemical Technology, University of Twente, P.O. Box 217, 7500 AE Enschede \\ (The Netherlands)
}

(Received 15 May 1989, revised manuscript received 9 August 1989)

\begin{abstract}
It has been found that it is possible to improve the activity and stability for the oxidative coupling of methane of a $\mathrm{Li} / \mathrm{MgO}$ catalyst by the addition of small amounts of the oxides of various transition and rare earth metals. A number of these additives, e.g. $\mathrm{SnO}_{2}, \mathrm{TiO}_{2}, \mathrm{Dy}_{2} \mathrm{O}_{3}$ and $\mathrm{Th}_{4} \mathrm{O}_{7}$, caused little or no difference in the selectivity to $\mathrm{C}_{2}$ products achieved with the resultant catalyst while considerably lowering the temperatures required to give the optimum yields of $\mathrm{C}_{2}$ products. Several other additives caused slight improvements (e.g. $\mathrm{La}_{2} \mathrm{O}_{3}$ and $\mathrm{NiO}$ ) without changing the selectivity and some lowered the temperature for a particular conversion (e.g. $\mathrm{CoO}, \mathrm{MnO}_{2}, \mathrm{PbO}$ and $\mathrm{Bi}_{2} \mathrm{O}_{3}$ ). A number of aspects of some of these catalysts are examined, including the nature of the phases present in the calcined materials, the decomposition of carbonate phases in the catalysts, the effect of promoter concentration and the ageing behaviour under oxidative coupling conditions. A comparison of the various systems shows that the $\mathrm{Li} / \mathrm{Sn} / \mathrm{MgO}$ is an extremely promising catalyst system for the oxidative coupling of methane.
\end{abstract}

\section{INTRODUCTION}

The oxidative coupling of methane to give ethane and ethylene is an interesting potential alternative to the conventional use of methane as a source of synthesis gas and derived products. Ito and Lunsford [1] and Ito et al. [2] have found that magnesium oxide doped with lithium oxide $(\mathrm{Li} / \mathrm{MgO})$ is a selective catalyst for the reaction. They proposed a mechanism in which surface $\mathrm{Li}^{+} \mathrm{O}^{-}$species constitute the active sites at which the reaction is initiated by the abstraction of a hydrogen from methane; ethane is then produced by coupling of two of the $\mathrm{CH}_{3}$ radicals thus formed. The subsequent (oxidative) dehydrogenation of ethane produces ethene while carbon monoxide and carbon dioxide are formed by attack of oxygen on the $\mathrm{CH}_{3}$ radicals. Recent work carried out on the same system in our laboratory has shown that the predominant route to carbon monoxide and carbon dioxide may instead be the oxi- 
dation of the ethylene formed from ethane, the latter being the primary product of the reaction [3].

In comparison with the very many other catalyst systems which have been investigated for this reaction, $\mathrm{Li} / \mathrm{MgO}$ catalysts give relatively very high selectivities to $\mathrm{C}_{2}$ products [4-6]; a comprehensive listing of the papers related to the methane coupling reaction has been published elsewhere [7]. The disadvantage of the $\mathrm{Li} / \mathrm{MgO}$ system is that the highest $\mathrm{C}_{2}$ selectivities and yields are reached at relatively high temperatures $\left(780^{\circ} \mathrm{C}\right)$. Under these conditions, the active sites created are not stable but are destroyed as a result of the loss of lithium $[4,5]$, either through reaction with the reactor wall $\left(\mathrm{SiO}_{2}\right.$ or $\left.\mathrm{Al}_{2} \mathrm{O}_{3}\right)$ or by the formation of the volatile $\mathrm{LiOH}$. Another disadvantageous feature of these high temperatures is that homogeneous gas-phase reactions begin to play a significant role, with the consequence that control of the selectivity of the catalyst by modification of its formulation is difficult to achieve.

Of the various other catalyst systems which have been studied [6], some of the most promising materials, first investigated by Otsuka et al., are the rare earth oxides [8]. These workers used highly diluted gas streams in most of their work, this almost certainly giving rise to the high selectives and yields which they reported. We have recently examined the behaviours of several rare earth oxides, $\mathrm{Sm}_{2} \mathrm{O}_{3}, \mathrm{La}_{2} \mathrm{O}_{3}$ and $\mathrm{Dy}_{2} \mathrm{O}_{3}$, under conditions identical to those which we had used for the $\mathrm{Li} / \mathrm{MgO}$ system and showed that these materials have relatively low $\mathrm{C}_{2}$ selectivities compared with those obtained with the $\mathrm{Li}$ / $\mathrm{MgO}$ system [6]; with a methane-to-oxygen ratio of ca. 10 , best $\mathrm{C}_{2}$ selectivity obtained with the former oxides was ca. $70 \%$ while the latter gave values up to ca. $83 \%$. The activities of the rare earth oxides were considerably higher than those of the $\mathrm{Li} / \mathrm{MgO}$ system, this being manifested in a considerable lowering of the temperature required to give a particular oxygen consumption.

An ideal catalyst would have high activities at relatively low temperatures while maintaining relatively high selectivities. With the intention of attempting to improve the activities and stabilities of materials based on the $\mathrm{Li} / \mathrm{MgO}$ system while maintaining the same $\mathrm{C}_{2}$ selectivities, we have examined the effect of adding a number of different oxides to a standard sample of $\mathrm{Li} / \mathrm{MgO}$; our initial work was carried out with the oxides of the rare earths $\mathrm{La}, \mathrm{Dy}$ and $\mathrm{Tb}$ as potential promoters, but the work was extended to oxides of $\mathrm{Sn}, \mathrm{Ti}, \mathrm{Ni}$, $\mathrm{V}, \mathrm{Zn}, \mathrm{Mo}$ and $\mathrm{Co}$ when it was found that oxides such as $\mathrm{Tb}_{4} \mathrm{O}_{7}$, in which the cation has a potentially variable valency, had a beneficial effect on the catalytic behaviour. (These materials are hereafter denoted as $\mathrm{Li} / \mathrm{X} / \mathrm{MgO}$, where $\mathrm{X}$ refers to the dopant oxide). The effect of dopant concentration was then examined for a number of the most promising of these materials $(X=S n, D y$ and $\mathrm{Co})$ and the decomposition of the carbonate species present in the catalysts. It is also shown that the addition of the promoter oxides results in a more stable behaviour of the catalysts. The role of lithium in the catalysts is discussed. 
EXPERIMENTAL

\section{Catalyst preparation}

The standard $\mathrm{Li} / \mathrm{MgO}$ material used in this work was prepared by wet impregnation of $\mathrm{Mg}(\mathrm{OH})_{2}$ with an aqueous solution of $\mathrm{LiOH}$; this was done in the presence of a stream of carbon dioxide [5]. After drying at $140^{\circ} \mathrm{C}$, this material was physically mixed with the various oxides. In all cases, the amount of promoter added was considerably less on a molar basis than the amount of lithium present; see Table 1. The samples were calcined in air at $850^{\circ} \mathrm{C}$ for 6 $\mathrm{h}$ and were then crushed and sieved to a grain size of $0.3-0.6 \mathrm{~mm}$ before use.

\section{TABLE 1}

Analysis, surface area and structure for the different catalyst samples used in this work

\begin{tabular}{|c|c|c|c|c|c|c|}
\hline Catlyst & $\begin{array}{l}\mathrm{Li} \\
\text { (wt.-\%) }\end{array}$ & $\mathrm{Li}$ & $\begin{array}{l}\mathrm{X} \\
(\mathrm{mmol} / \mathrm{g})\end{array}$ & $\mathrm{CO}_{2}$ & $\begin{array}{l}\text { Area } \\
\left(\mathrm{m}^{2} / \mathrm{g}\right)\end{array}$ & XRD \\
\hline $\mathrm{Li} / \mathrm{MgO}$ & 2.34 & 3.37 & abs & 1.53 & 2.4 & $a$ \\
\hline $\mathrm{Li} / \mathrm{Zn} / \mathrm{MgO}$ & 4.28 & 6.17 & 0.229 & 2.68 & - & - \\
\hline $\mathrm{Li} / \mathrm{Ca} / \mathrm{MgO}$ & 2.78 & 4.00 & 0.314 & 1.56 & - & $a$ \\
\hline $\mathrm{Li} / \mathrm{V} / \mathrm{MgO}$ & 2.99 & 4.31 & 0.324 & 1.61 & 0.5 & $a$ \\
\hline $\mathrm{Li} / \mathrm{Ni} / \mathrm{MgO}$ & 3.28 & 4.72 & 0.261 & 2.25 & 0.5 & $a$ \\
\hline $\mathrm{I}, \mathrm{i} / \mathrm{I}$ a $/ \mathrm{MgO}$ & 3.85 & 5.55 & 0.211 & 2.64 & 1.5 & $\mathrm{I} a(\mathrm{OH})_{3}, \mathrm{I}, \mathrm{iI} \mathrm{aO}_{2}$ \\
\hline $\mathrm{Li} / \mathrm{Tb} / \mathrm{MgO}$ & 4.36 & 6.28 & 0.233 & 2.69 & - & - \\
\hline \multicolumn{7}{|l|}{$\mathrm{Li} / \mathrm{Dy} / \mathrm{MgO}$} \\
\hline a & 4.24 & 5.97 & 0.579 & 2.04 & - & \multirow{2}{*}{$\underset{a}{\mathrm{Dy}_{2} \mathrm{O}_{3}, \mathrm{LiDyO}_{2}}$} \\
\hline $\mathrm{b}$ & 5.74 & 8.27 & 1.414 & 2.55 & - & \\
\hline \multicolumn{7}{|l|}{$\mathrm{Li} / \mathrm{Sn} / \mathrm{MgO}$} \\
\hline a & 4.77 & 6.87 & 0.029 & 2.30 & - & $a$ \\
\hline b & 3.99 & 5.75 & 0.206 & 2.80 & 5.0 & $a$ \\
\hline $\mathrm{c}$ & 3.91 & 5.63 & 0.460 & 1.94 & - & $a$ \\
\hline $\mathrm{Li} / \mathrm{Ti} / \mathrm{MgO}$ & 3.37 & 4.85 & 0.221 & - & 1.9 & $a$ \\
\hline \multicolumn{7}{|l|}{$\mathrm{Li} / \mathrm{Co} / \mathrm{MgO}$} \\
\hline a & 3.98 & 5.73 & 0.238 & 2.36 & 1.5 & $a$ \\
\hline b & 4.77 & 6.86 & 0.973 & 2.13 & - & - \\
\hline $\mathrm{c}$ & 4.74 & 6.83 & 2.343 & 1.68 & - & - \\
\hline $\mathrm{Li} / \mathrm{Mn} / \mathrm{MgO}$ & 3.91 & 5.63 & 0.781 & 2.18 & 3.7 & $\mathrm{MnO}_{2}, \mathrm{LiMnO}_{3}$ \\
\hline $\mathrm{Li} / \mathrm{Mo} / \mathrm{MgO}$ & 4.31 & 6.21 & 0.322 & 1.69 & - & - \\
\hline $\mathrm{Li} / \mathrm{Bi} / \mathrm{MgO}$ & 3.88 & 5.59 & 0.208 & 2.60 & - & - \\
\hline $\mathrm{Li} / \mathrm{Pb} / \mathrm{MgO}$ & 4.73 & 6.82 & 0.226 & 2.59 & - & - \\
\hline
\end{tabular}

${ }^{a} \mathrm{Li}_{2} \mathrm{CO}_{3}$ and $\mathrm{MgO}$.

abs: absent.

- : not measured. 
Elemental analysis was carried out with absorption spectroscopy (AAS) and $\mathrm{X}$-ray fluorescence (XRF). The carbonate contents were determined by wet analysis using the Blom-Edelhausen method. X-ray powder diffraction was carried out with a Philips P.W. 1710 diffractometer using $\mathrm{Cu} \mathrm{K} \alpha$ radiation. Surface areas were determined using argon adsorption. The decomposition of the carbonate species on the samples was measured using a temperature-programmed desorption (TPD) system; this is a flow system equipped with a thermal conductivity cell in which the sample was heated at a constant rate $\left(14^{\circ} \mathrm{C} / \mathrm{min}\right)$ in a stream of helium. Table 1 gives the compositions (expressed as both wt. $\%$ and $\mathrm{mmol} / \mathrm{g}$ ) after calcination at $850^{\circ} \mathrm{C}$ of the various samples studied, their surface areas and any additional phases shown to be present by $\mathrm{X}$-ray measurements. It should be noted that although the starting lithium content for each sample was the same, the values shown in the table show considerable variation, probably due to different degrees of loss of litium species during the calcination step in the different systems.

\section{Catalytic experiments}

The catalytic experiments were carried out in a fixed bed reactor, gas analysis being carried out with gas chromatography [9]. The gas composition was $P_{\mathrm{CH}_{4}}=0.67$ bar, $p_{\mathrm{O}_{2}}=0.07$ bar and $p_{\mathrm{He}}=0.26$ bar; the catalyst weight, $W$ was $0.750 \mathrm{~g}$ and the total gas flow, $f$, was $3.33 \mathrm{~cm}^{3}(\mathrm{STP}) \mathrm{s}^{-3}$.

\section{RESULTS AND DISCUSSION}

\section{The effect of the addition of various oxides to $\mathrm{Li} / \mathrm{MgO}$}

Fig. 1 shows the measured $\mathrm{C}_{2}$ yields as a function of the reaction temperature, $T_{\mathrm{R}}$, for a number of the catalysts listed in Table 1; the results of an unpromoted $\mathrm{Li} / \mathrm{MgO}$ sample are shown for comparison. Addition of $\mathrm{La}_{2} \mathrm{O}_{3}, \mathrm{~Tb}_{4} \mathrm{O}_{7}$ and $\mathrm{Dy}_{2} \mathrm{O}_{3}$ has a substantial beneficial effect, the latter two oxides having a greater promotional effect than the former. This is rather surprising, as previous work using unsupported $\mathrm{Tb}_{4} \mathrm{O}_{7}$ showed that this oxide, which can be partially reduced, gave almost exclusively total oxidation, from which we had concluded that oxides of metals with variable valencies are to be avoided for oxidative methane coupling when methane and oxygen are fed to the catalyst together [6]. We therefore decided to extend the range of oxides studied to materials other than the rare earths. The results for the addition of $\mathrm{SnO}_{2}$ and $\mathrm{ZnO}$ are also shown in Fig. 1 and those for the addition of $\mathrm{MoO}_{3}$ and $\mathrm{CoO}$ are shown in Fig. 2. The results of Figs. 1 and 2, together with those of experiments with the addition of $\mathrm{CaO}, \mathrm{NiO}, \mathrm{TiO}_{2}$ and $\mathrm{MnO}_{2}$ which are not shown graphi- 


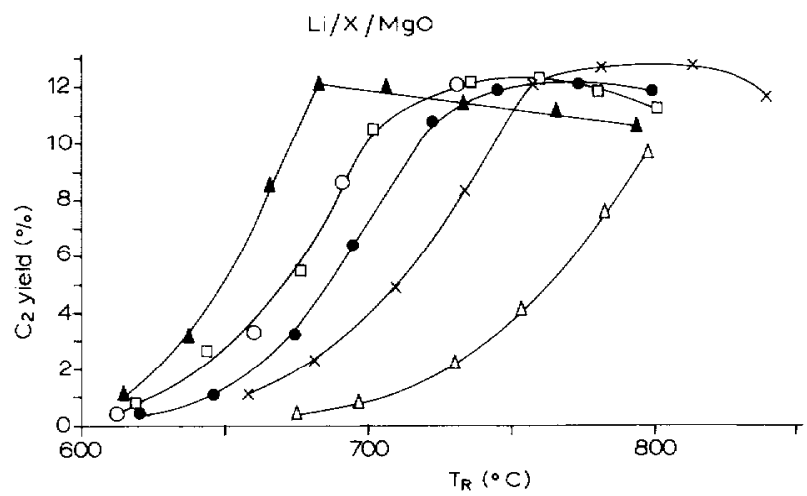

Fig. 1. The $\mathrm{C}_{2}$ yield as a function of $T_{\mathrm{R}}$ for a number of the promoted $\mathrm{Li} / \mathrm{MgO}$ catalysts compared with the results for an unpromoted $\mathrm{Li} / \mathrm{MgO}$ sample. $(\triangle) \mathrm{Li} / \mathrm{Zn} / \mathrm{MgO},(\times) \mathrm{Li} / \mathrm{MgO},(\triangle) \mathrm{Li} /$ $\mathrm{La} / \mathrm{MgO}$, ( $\square$ ) Li/Tb/MgO, (O) Li/Dy/MgO a, ( $\Delta$ ) Li/Sn/MgO b.

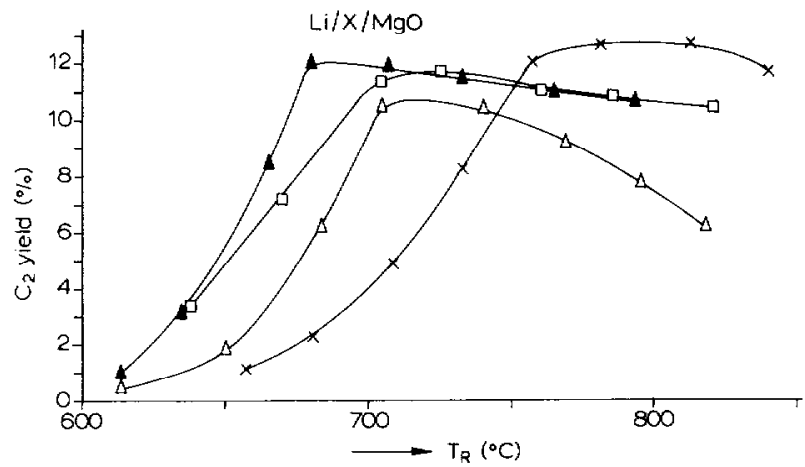

Fig. 2. The $\mathrm{C}_{2}$ yield as a function of $T_{\mathrm{R}}$ for a number of the promoted $\mathrm{Li} / \mathrm{MgO}$ catalysts compared with the results for an unpromoted $\mathrm{Li} / \mathrm{MgO}$ sample. $(\times) \mathrm{Li} / \mathrm{MgO},(\triangle) \mathrm{Li} / \mathrm{Mo} / \mathrm{MgO},(\square) \mathrm{Li} /$ $\mathrm{Co} / \mathrm{MgO}$ a, ( $\mathbf{\Delta}) \mathrm{Li} / \mathrm{Sn} / \mathrm{MgO}$ b.

cally, are summarised in Table 2; this gives the temperature required to give oxygen conversions of 50 and $90 \%$, the lowering (relative to the unpromoted catalyst) of the temperature required to give these oxygen conversions, and the corresponding $\mathrm{C}_{2}$ selectivities.

The addition of $\mathrm{SnO}_{2}$ to $\mathrm{Li} / \mathrm{MgO}$ (Fig. 1) was found to give a very significant improvement to the activity of the catalyst (lowering of $T_{R}$ ); the same $\mathrm{C}_{2}$ selectivity and $\mathrm{C}_{2}$ yield were reached at this lower reaction temperature as those obtained at the higher optimum temperature for the unpromoted catalyst. Fig. 2 and Table 2 show that analogous results were obtained when the oxides of $\mathrm{V}$, $\mathrm{Ni}$, Ti and Mo were added to $\mathrm{Li} / \mathrm{MgO}$. The addition of $\mathrm{ZnO}$ (Fig. 1 and Table 1) had a detrimental effect on the catalytic activity, the reaction temperature for a given conversion being increased significantly. The addition of $\mathrm{CaO}$ had 
TABLE 2

Catalytic results for $\mathrm{Li} / \mathrm{X} / \mathrm{MgO}$ catalysts, showing the temperatures for oxygen conversions of $50 \%$ and $90 \%$, the corresponding difference in temperature $(\Delta T)$ between these results and those for $\mathrm{Li} / \mathrm{MgO}$, and the corresponding $\mathrm{C}_{2}$ selectivities

\begin{tabular}{|c|c|c|c|c|c|c|}
\hline \multirow[t]{2}{*}{ Catalyst } & \multicolumn{3}{|c|}{$50 \% \mathrm{O}_{2}$ conversion } & \multicolumn{3}{|c|}{$90 \% \mathrm{O}_{2}$ conversion } \\
\hline & $\begin{array}{l}T \\
\left({ }^{\circ} \mathrm{C}\right)\end{array}$ & $\begin{array}{l}\Delta T \\
\left({ }^{\circ} \mathrm{C}\right)\end{array}$ & $\begin{array}{l}S_{2} \\
(\%)\end{array}$ & $\begin{array}{l}T \\
\left({ }^{\circ} \mathrm{C}\right)\end{array}$ & $\begin{array}{l}\Delta T \\
\left({ }^{\circ} \mathrm{C}\right)\end{array}$ & $\begin{array}{l}S_{2} \\
(\%)\end{array}$ \\
\hline $\mathrm{Li} / \mathrm{Zn} / \mathrm{MgO}$ & 773 & 48 & 85 & 806 & 48 & 86 \\
\hline $\mathrm{Li} / \mathrm{MgO}$ & 725 & - & 85 & 758 & - & 85 \\
\hline $\mathrm{Li} / \mathrm{Ca} / \mathrm{MgO}$ & 725 & 0 & 83 & 758 & 0 & 84 \\
\hline $\mathrm{Li} / \mathrm{V} / \mathrm{MgO}$ & 712 & -13 & 78 & 745 & -13 & 79 \\
\hline $\mathrm{Li} / \mathrm{Ni} / \mathrm{MgO}$ & 700 & -25 & 78 & 740 & -18 & 81 \\
\hline $\mathrm{Li} / \mathrm{La} / \mathrm{MgO}$ & 693 & -32 & 84 & 724 & -34 & 85 \\
\hline $\mathrm{Li} / \mathrm{Dy} / \mathrm{Mgo} \mathrm{a}^{a}$ & 678 & -47 & 83 & 711 & -47 & 84 \\
\hline $\mathrm{Li} / \mathrm{Tb} / \mathrm{MgO}$ & 675 & -50 & 82 & 701 & -57 & 82 \\
\hline $\mathrm{Li} / \mathrm{Sn} / \mathrm{MgO}^{a}$ & 655 & -70 & 78 & 680 & -78 & 84 \\
\hline $\mathrm{Li} / \mathrm{Ti} / \mathrm{MgO}$ & 655 & -70 & 70 & 690 & -68 & 78 \\
\hline $\mathrm{Li} / \mathrm{Co} / \mathrm{MgO}^{a}$ & 610 & -115 & 0 & 690 & -68 & 78 \\
\hline $\mathrm{Li} / \mathrm{Mo} / \mathrm{MgO}$ & 680 & -45 & 68 & 725 & -33 & 71 \\
\hline $\mathrm{Li} / \mathrm{Mn} / \mathrm{MgO}$ & - & - & - & 640 & -118 & 39 \\
\hline $\mathrm{Li} / \mathrm{Pb} / \mathrm{MgO}$ & 640 & -85 & 23 & 672 & -80 & 50 \\
\hline $\mathrm{Li} / \mathrm{Bi} / \mathrm{MgO}$ & 712 & -13 & 67 & 750 & -8 & 65 \\
\hline
\end{tabular}

${ }^{a}$ see Table 1.

no effect on the behaviour. The result for the addition of the oxides of $\mathrm{Co}, \mathrm{Mn}$, $\mathrm{Pb}$, and $\mathrm{Bi}$ (Table 2) were somewhat different and will be discussed below.

The selectivity behaviour of a number of the samples with respect to reaction temperature were similar to the behaviour of the un-modified $\mathrm{Li} / \mathrm{MgO}$ material: only at very low temperatures were the reaction products predominantly carbon monoxide and carbon dioxide but $\mathrm{C}_{2}$ production started at low oxygen conversions (ca. $3-4 \%$ ) and the $\mathrm{C}_{2}$ selectivity soon reached, with increasing temperature, the steady levels given in Table 2 . The selectivities of the samples promoted by $\mathrm{Zn}, \mathrm{Ca}, \mathrm{La}$, Dy and $\mathrm{Tb}$ were similar to the unpromoted material while the selectivities of the materials promoted by $\mathrm{V}, \mathrm{Ni}, \mathrm{Ti}, \mathrm{Mo}$ and $\mathrm{Bi}$ were slightly lower; in the case of the bismuth-containing sample, considerable loss of volatile bismuth species took place. For the tin-promoted material, the selectivity was slightly lower at the temperature giving $50 \%$ oxygen conversion but reached the level of the unpromoted material at higher conversion.

Addition of $\mathrm{CoO}$ gave a material which was active and non-selective at a very low temperature; it still had $100 \%$ selectivity to carbon dioxide at $50 \%$ oxygen conversion. However, when the temperature was increased to give an oxygen conversion of $90 \%$, the $\mathrm{C}_{2}$ selectivity approached that of a number of the other promoted catalysts. On cooling once more, there was a small increase in $\mathrm{C}_{2}$ 
selectivity. The change in behaviour with heating appears to have something to do with the mobility or volatility of the lithium species. At a very low reaction temperature of $610^{\circ} \mathrm{C}$, the mobility is likely to be very low and bare CoO sites are accessible, these giving total oxidation; when the temperature is increased, the lithium species become mobile and possibly also volatile [10], and this has a beneficial effect on the selectivity. After cooling, the lithium is probably better spread on the surface of the catalyst. These effects are only seen at very low conversions with the other catalysts (see above) as these materials do not become significantly active until those temperatures at which the lithium becomes mobile.

The addition of $\mathrm{MnO}_{2}$ also gave anomalous results; see Table 2. Although this additive gave a considerable lowering of the temperature required to give $90 \%$ oxygen conversion (the oxygen conversion was above $50 \%$ at lowest temperature used), the selectivity at this temperature was very low. As with $\mathrm{CoO}$, a further increase in the temperature (giving ca. $100 \%$ oxygen conversion) gave and improvement in the selectivity, this again probably being associated with increased mobility of the lithium species. It is interesting to note that manganese based catalysts have been shown to be very effective for methane coupling in the cyclic mode of operation [11]; it thus seems that these materials contain sites which give total oxidation if exposed to methane in the presence of molecular oxygen if not coated with mobile lithium species. Similar observations have recently been made by $\mathrm{Burch}$ et al. [12] for a $\mathrm{MnO}_{2}$ catalyst using a co-flow system; they found that the selectivity of their material could be much improved by the addition of $\mathrm{LiCl}$. It is possible that our manganese promoted materials could also be improved by the addition of chlorine species.

In only a few cases was the formation of compounds of lithium in the promoted materials shown by XRD; the compounds detected were $\mathrm{LiLaO}_{2}$, $\mathrm{LiDyO}_{2}$ and $\mathrm{Li}_{2} \mathrm{MnO}_{3}$. In the other cases examined, XRD showed only the presence of $\mathrm{Li}_{2} \mathrm{CO}_{2}$ and $\mathrm{MgO}$; see Table 1 . It is therefore unlikely that the presence of new surface compounds involving lithium is responsible for the improved properties of a number of the materials.

The surface areas of a number of the catalysts are shown in Table 1. There is no significant change on the addition of the promoters and a comparison of these data with catalytic results of Table 2 allow us to conclude that an increase of area is not responsible for the improvement of the catalytic behaviour; for example, although the vanadium and nickel promoted materials are active at lower temperature, their areas $\left(0.5 \mathrm{~m}^{2} / \mathrm{g}\right)$ are somewhat lower than that of the unpromoted material $\left(2.4 \mathrm{~m}^{2} / \mathrm{g}\right)$.

The effect of promoters on the $\mathrm{Li} / \mathrm{MgO}$ system has also been reported by several other groups. Larkins and Nordin [13] have given results for the addition of transition metal oxides to a $6 \mathrm{wt}$. $\% \mathrm{Li} / \mathrm{MgO}$ catalyst. They found that addition of $\mathrm{Mn}, \mathrm{Fe}$ or Co at concentrations of 2 mol-\% (relative to lithium ) resulted in an increased conversion and an increased $\mathrm{C}_{2}$ selectivity at 
$T_{\mathrm{R}}=800^{\circ} \mathrm{C}$. Yingli et al. [14] showed that it was possible to improve the activity and selectivity of the $\mathrm{Li} / \mathrm{MgO}$ catalyst by the addition of cerium oxide. This result was also found by Bartsch et al. [15].

\section{The effect of content of the added oxide}

Fig. 3 shows the values of the $\mathrm{C}_{2}$ yield as a function of $T_{\mathrm{R}}$ for $\mathrm{Li} / \mathrm{Sn} / \mathrm{MgO}$ materials with different tin contents; the results for the unpromoted material are again shown for comparison. The addition of only a small amount of tin was sufficient to give a large increase in activity. When more tin was added, there was a further small increase in activity at relatively low $T_{R}$; however, at higher reaction temperatures there was a decrease in $\mathrm{C}_{2}$ production, this being caused by a decrease in $\mathrm{C}_{2}$ selectivity. The maximum $\mathrm{C}_{2}$ yield which could be reached decreased with increasing tin content and total oxidation became more important. In the experiments at the high reaction temperatures, samples were taken from the reactor effluent and were analysed for components which could not be separated with the $\mathrm{GC}$ column of the system used; no $\mathrm{C}_{3}, \mathrm{C}_{4}$ or $\mathrm{C}_{5}$ components could be found.

Analogous results to those for the tin-doped system were found for the $\mathrm{Li}$ / $\mathrm{Dy} / \mathrm{MgO}$ and $\mathrm{Li} / \mathrm{Co} / \mathrm{MgO}$ systems (Figs. 4 and 5). As expected, the effect of increasing promoter concentration was far less pronounced for the addition of $\mathrm{Dy}_{2} \mathrm{O}_{3}$ than that of $\mathrm{SnO}_{2}$ since this oxide by itself is a relatively selective catalyst for methane coupling [6]. In the case of the addition of $\mathrm{CoO}$ (Fig. 5), the results were very different. At low temperatures, the results for the $\mathrm{C}_{2}$ yields show little change with increase of cobalt content; the data have approximately the same form as those shown in Fig. 4 and the cobalt content has little or no effect. However, as noted above, the selectivity in this range of temperature was relatively very low, probably due to the exposure of unpromoted $\mathrm{CoO}$ sites.

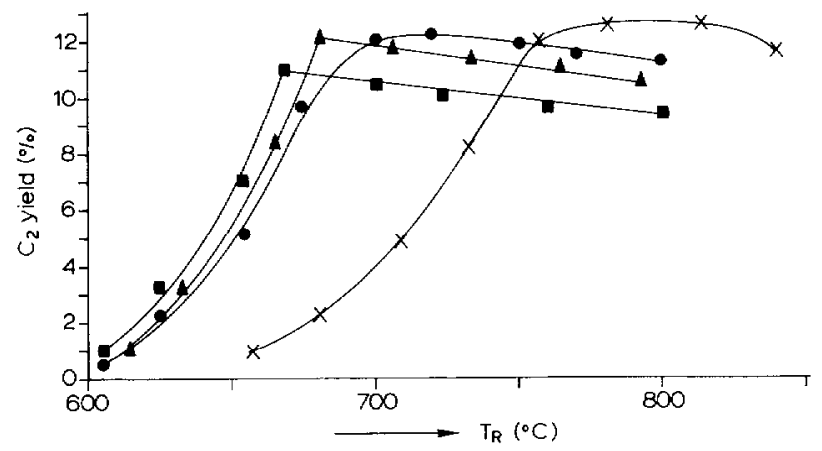

Fig. 3. The $\mathrm{C}_{2}$ yield as a function of $T_{\mathrm{R}}$ for $\mathrm{Li} / \mathrm{Sn} / \mathrm{MgO}$ materials with different tin contents; the results for the unpromoted material are shown for comparison. $(\times) \mathrm{Li} / \mathrm{MgO} ; \mathrm{Li} / \mathrm{Sn} / \mathrm{MgO}:(\mathbf{O})$ $0.029 \mathrm{mmol} \mathrm{Sn} / \mathrm{g}$, (A) $0.206 \mathrm{mmol} \mathrm{Sn} / \mathrm{g}$, ( $) 0.460 \mathrm{mmol} \mathrm{Sn} / \mathrm{g}$. 


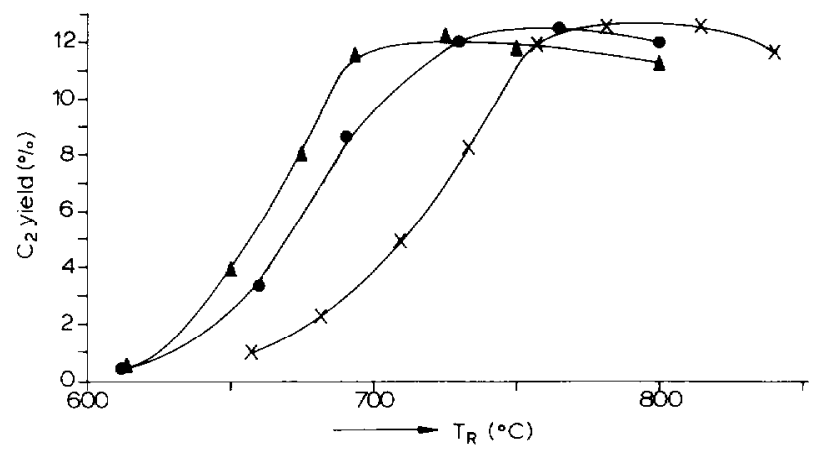

Fig. 4. The $\mathrm{C}_{2}$ yield as a function of $T_{\mathrm{R}}$ for $\mathrm{Li} / \mathrm{Dy} / \mathrm{MgO}$ materials with different dysprosium contents; the results for the unpromoted material are shown for comparison. $(X) \mathrm{Li} / \mathrm{MgO} ; \mathrm{Li}$ / $\mathrm{Dy} / \mathrm{MgO}:(\odot) 0.579 \mathrm{mmol} \mathrm{Dy} / \mathrm{g}$, ( 4 ) $1.414 \mathrm{mmol} \mathrm{Dy} / \mathrm{g}$.

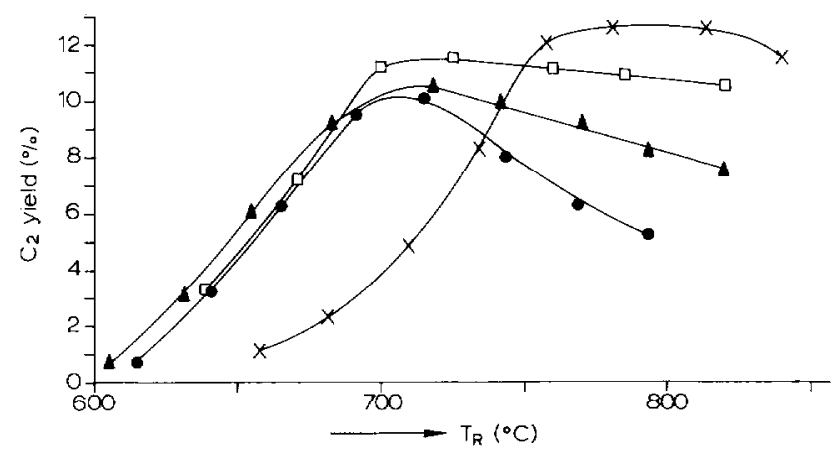

Fig. 5. The $\mathrm{C}_{2}$ yield as a function of $T_{\mathrm{R}}$ for $\mathrm{Li} / \mathrm{Co} / \mathrm{MgO}$ materials with different cobalt contents; the results for the unpromoted material are shown for comparison. (X) $\mathrm{Li} / \mathrm{MgO} ; \mathrm{Li} / \mathrm{Co} / \mathrm{MgO}$ : (ㅁ) $0.238 \mathrm{mmol} \mathrm{Co} / \mathrm{g}$, (A) $0.973 \mathrm{mmol} \mathrm{Co} / \mathrm{g}$, (○) $2.343 \mathrm{mmol} \mathrm{Co} / \mathrm{g}$.

The fact that the cobalt content has little effect seems to indicate that the exposed $\mathrm{CoO}$ surface is little changed by the increase and that only the lithium species are responsible for the $\mathrm{C}_{2}$ yields observed in this temperature range. The results for higher temperatures are also rather different from those for the other materials: the yield now drops off substantially with increasing temperature, the extent of this effect increasing with cobalt content; this is due largely to a decrease in $\mathrm{C}_{2}$ selectivity. Although we do yet have direct evidence to support our arguments, we suggest that the decrease in selectivity at higher temperatures may be due to the reversible loss of active species due to the occurrence of the reaction:

$\mathrm{Li}_{2} \mathrm{CO}_{3}=\mathrm{Li}_{2} \mathrm{O}+\mathrm{CO}_{2}$

We have argued previously that the activity and selectivity of $\mathrm{Li} / \mathrm{MgO}$ cata- 
lysts is associated with sites created by the decomposition of $\mathrm{Li}_{2} \mathrm{CO}_{3}$ species under reaction conditions and that the species involved may be $\mathrm{O}^{-}, \mathrm{O}_{2}^{-}$or $\mathrm{O}_{2}^{2-}$ entities. As the amount of carbonate decreases on increasing the temperature, the number of such potential coupling sites will also decrease; this has the consequence that the effect of the $\mathrm{CoO}$ again becomes more noticeable and that the yield begins to drop with increasing temperature. Although X-ray diffraction failed to show the information of any new compounds when cobalt was added, it is tempting to speculate that some sort of surface complex is formed between the cobalt and lithium species, the consequence being that less free lithium is available at higher cobalt contents; alternatively, the $\mathrm{CoO}$ may have some effect on the decomposition of the carbonate, bringing its decomposition about more easily. These suggestions would both explain the more pronounced drop of yield with temperature at higher cobalt contents compared with undoped samples.

\section{The oxidation of ethane and ethylene}

The catalysts $\mathrm{Li} / \mathrm{Sn} / \mathrm{MgO}$ (b), $\mathrm{Li} / \mathrm{Dy} / \mathrm{MgO}$ (a) and $\mathrm{Li} / \mathrm{MgO}$ were also tested for the oxidative dehydrogenation of ethane to ethylene and for ethylene oxidation. The sequence of activity reported above for the oxidative coupling reaction over these materials was found to be: $\mathrm{Li} / \mathrm{Sn} / \mathrm{MgO}(\mathrm{b})>\mathrm{Li} / \mathrm{Dy} / \mathrm{MgO}$ (a) $>\mathrm{Li} / \mathrm{MgO}$. Without giving details of the results, it can be stated that the same sequence of activity was found for the oxidative dehydrogenation of ethane and for the oxidation of ethylene.

In previous publications $[3,16]$, we showed that the oxidation reactions of ethane and ethylene are important steps in the all-over reaction network for the oxidative coupling of methane over a $\mathrm{Li} / \mathrm{MgO}$ catalyst and we suggested that the main reaction sequence is as follows:

$$
\begin{aligned}
& 2 \mathrm{CH}_{4}+1 / 2 \mathrm{O}_{2} \rightarrow \mathrm{C}_{2} \mathrm{H}_{6}+\mathrm{H}_{2} \mathrm{O} \\
& \mathrm{C}_{2} \mathrm{H}_{6}+1 / 2 \mathrm{O}_{2} \rightarrow \mathrm{C}_{2} \mathrm{H}_{4}+\mathrm{H}_{2} \mathrm{O} \\
& \mathrm{C}_{2} \mathrm{H}_{4}+3 \mathrm{O}_{2} \rightarrow 2 \mathrm{CO}_{2}+2 \mathrm{H}_{2} \mathrm{O}
\end{aligned}
$$

The observation that the addition of promoters does not give an increase in the maximum $\mathrm{C}_{2}$ yield reached would seem to indicate that the promoters affect all of these constituent reactions in the same way and to approximately the same extent.

\section{The function of $\mathrm{Li}_{2} \mathrm{CO}_{3}$}

As discussed above, we have previously suggested a possible model for the reactions which occur on the surface of $\mathrm{Li} / \mathrm{MgO}$ catalysts $[5,17]$ in which active sites are created on the surface in the presence of oxygen by the gradual 
loss of carbon dioxide from surface lithium carbonate species. A relationship was found previously between $T_{\mathrm{d}}$, the temperature at which the decomposition of the $\mathrm{Li}_{2} \mathrm{CO}_{3}$ on $\mathrm{MgO}$ starts, and the activity of the catalyst; $\mathrm{Li} / \mathrm{MgO}$ catalysts with a high value of $T_{\mathrm{d}}$ were found to be relatively inactive. It was therefore of interest to know whether or not there is a significant interaction between the $\mathrm{Li}_{2} \mathrm{CO}_{3}$ and the promoters added to the catalyst and whether the promoters affected the decomposition of the carbonate species. To examine this point further, TPD experiments were carried out using the various catalysts to examine the decomposition behaviour of the carbonates.

The decomposition profiles of a number of the samples are given in Fig. 6 . It can be seen that there is a variation in the decomposition behaviour relative to that of the unpromoted material; this variation entails a small variation of the position of the peak and also of its shape. For example, the peak for the $\mathrm{Li} / \mathrm{Sn} / \mathrm{MgO}$ material begins at a somewhat lower temperature than that for the unpromoted material and the same applies for the $\mathrm{Li} / \mathrm{Dy} / \mathrm{MgO}$ material; it is therefore tempting to suggest that there is some sort of correlation between the temperature of onset of the decomposition behaviour and the temperature for the optimum yields for these materials (see Fig. 1). However, no convincing correlation emerged for the other materials, even though the data exhibited a distinct trend, and so no graphical attempt at a correlation is shown.

The addition of $\mathrm{ZnO}$ increased the decomposition temperature of the carbonate, resulting in a relatively inactive catalyst. The relative inactivity of this system may have been caused by the formation of an inactive $\mathrm{Li}-\mathrm{Zn}$ carbonate melt on the surface of the catalyst at the relatively high calcination temperature of $850^{\circ} \mathrm{C}$ used [18].

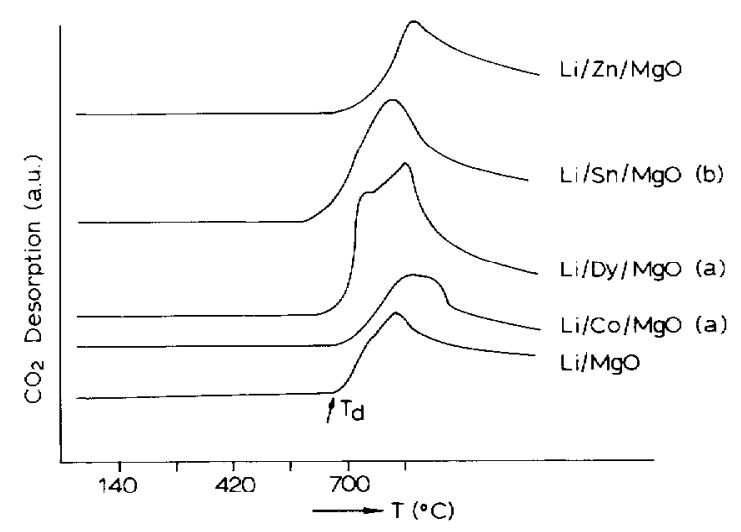

Fig. 6. The rate of desorption of carbon dioxide from $\mathrm{Li} / \mathrm{X} / \mathrm{MgO}$ catalysts as a function of temperature. 
It is known from literature [19] that the oxides which we have added as promoters all adsorb oxygen more strongly than do (almost) non-conducting materials such as $\mathrm{Li} / \mathrm{MgO}$ and $\mathrm{Li} / \mathrm{CaO}$. It is known that oxides such as $\mathrm{CoO}$, $\mathrm{NiO}$ and $\mathrm{MnO}$ (p-type conductors) strongly adsorb oxygen, in the form of electron-rich species, while oxides as $\mathrm{SnO}_{2}, \mathrm{TiO}_{2}$, and $\mathrm{V}_{2} \mathrm{O}_{5}$ (n-type conductors) adsorb oxygen more weakly, in the form of species less rich in electrons. It seems reasonable to assume that the interaction of oxygen with the catalyst will be enhanced by the addition of these oxides, resulting in an improved oxygen adsorption. On account of this enhanced oxygen adsorption, the interaction of methane with the catalyst would also be improved. Kinetic measurements, which will be described in detail elsewhere [20], indeed showed an improved oxygen and methane adsorption of the $\mathrm{Li} / \mathrm{Sn} / \mathrm{MgO}$ catalyst when compared with the $\mathrm{Li} / \mathrm{MgO}$ catalyst.

The mobile $\mathrm{Li}_{2} \mathrm{CO}_{3}$ probably has two functions:

(i) It inhibits total oxidation by preventing strong oxygen adsorption on the added promoter oxide.

(ii) It creates active sites on the surface in the presence of oxygen by the gradual loss of carbon dioxide from surface lithium carbonate species $\left(T>T_{\mathrm{d}}\right)$ [5].

An alternative role of the promoter can be to stabilise the lithium in an active form.

The stability of $\mathrm{Li} / \mathrm{X} / \mathrm{MgO}$ catalysts

A significant disadvantage of the use of $\mathrm{Li} / \mathrm{MgO}$ catalysts in the coupling of methane is in the poor stability of these materials $[4,5]$. We have therefore examined a number of aspects of the stability of promoted $\mathrm{Li} / \mathrm{X} / \mathrm{MgO}$ catalysts and the results will be presented in the following paragraphs.

\section{Effect of calcination}

Results from the analyses of the lithium contents after calcination at $850^{\circ} \mathrm{C}$, which are given in Table 1 , showed that all of the promoted materials contained more lithium than did the unpromoted $\mathrm{Li} / \mathrm{MgO}$ material after the same treatment. Since the same uncalcined $\mathrm{Li} / \mathrm{MgO}$ precursor was used in the preparation of all the samples, we can conclude that the loss of lithium occurring during calcination was reduced by the presence of the added oxide; it can be seen that small amounts of the oxide of the species $\mathrm{X}$ relative (on a molar basis) to the amount of lithium in the materials are sufficient to reduce the loss of lithium. This is particularly so for the first catalyst (sample a) in the series of tindoped materials: that is the addition of $0.029 \mathrm{mmol} \mathrm{g}^{-1}$ of $\mathrm{Sn}^{4+}$ gave an increase in the retention of the lithium content (compared with the undoped Li/ 
$\mathrm{MgO}$ material) of more than $3 \mathrm{mmol} \mathrm{g}^{-1}$. It is interesting to note that the addition of higher amounts of tin resulted in a decreased effect (i.e. lower lithium contents in the calcined materials) while the addition of increasing amounts of dysprosium or cobalt gave improved stabilising effects. These results provide additional evidence for the suggestion made above that there is a relatively strong interaction between the promoter and the lithium species in the catalysts and indicate that this interaction exists even under conditions in which no catalytic reaction is carried out.

\section{Ageing experiments}

Fig. 7 shows the $\mathrm{C}_{2}$ yield as a function of time on stream at $T_{\mathrm{R}}=760^{\circ} \mathrm{C}$ in a quartz reactor for the three catalysts samples: $\mathrm{Li} / \mathrm{MgO}, \mathrm{Li} / \mathrm{La} / \mathrm{MgO}$ and $\mathrm{Li} /$ $\mathrm{Dy} / \mathrm{MgO}(\mathrm{a})$; the lithium contents of the samples after use are given in parentheses. The $\mathrm{C}_{2}$ selectivities of both the promoted samples throughout these experiments were $82 \%$. Similar results are given in Fig. 8 for samples of $\mathrm{Li} /$ $\mathrm{MgO}$ and $\mathrm{Li} / \mathrm{Sn} / \mathrm{MgO}$ (a) and (b) for reaction in an alumina reactor; there was in this case no loss of tin from the samples after use. The $\mathrm{C}_{2}$ selectivities for the promoted samples were ca. $79 \%$ throughout the experiments. It can be seen from both figures that the promoted materials behaved much better than did the unpromoted materials. Furthermore, the addition of the promoter brought about a large decrease in the loss of lithium in each case. The temperature chosen for these comparative ageing experiments was that at which the optimum behaviour was achieved for the unpromoted $\mathrm{Li} / \mathrm{MgO}$ sample, it is clearly well above the temperature at which the optimum behaviour was found with the promoted $\mathrm{Li} / \mathrm{X} / \mathrm{MgO}$ samples (Figs. 1-5).

As discussed above the deactivation of the unpromoted $\mathrm{Li} / \mathrm{MgO}$ material is caused by the loss of lithium due to the formation of $\mathrm{Li}_{2} \mathrm{SiO}_{3}$ by reaction with the quartz of the reaction vessel or by the evaporation of the volatile species

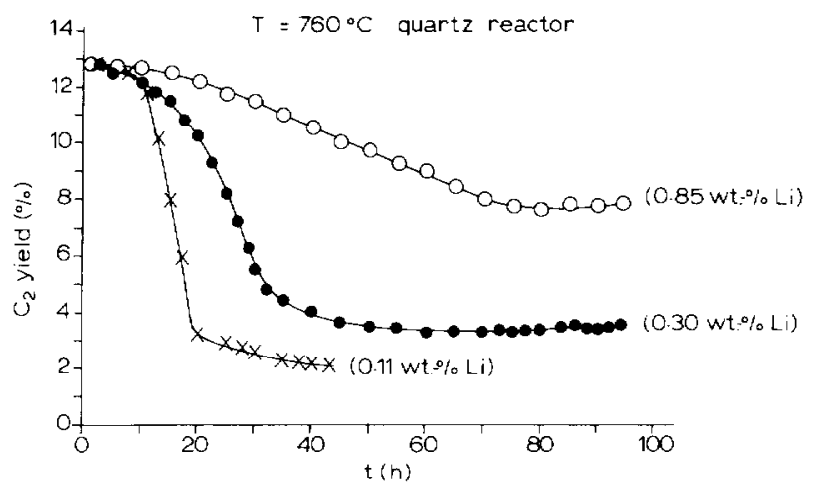

Fig. 7. The $\mathrm{C}_{2}$ yield as a function of time on stream at $T_{\mathrm{R}}=760^{\circ} \mathrm{C}$ in a quartz reactor for $\mathrm{Li} / \mathrm{MgO}$ $(\times), \mathrm{Li} / \mathrm{La} / \mathrm{MgO}(\odot)$ and $\mathrm{Li} / \mathrm{Dy} / \mathrm{MgO}(\mathrm{a})(\mathrm{O})$. 
$\mathrm{LiOH}$ [5]. As can be seen from the lithium analysis carried out after the experiments of Figs. 7 and 8, the loss of lithium was reduced by the addition of the promoter oxide. This improved stability is similar to that discussed above in relation to the decreased loss of lithium after calcination; in particular, for the samples promoted by the oxides of lanthanum and dysprosium, the compounds $\mathrm{LiLaO}_{2}$ and $\mathrm{LiDyO}_{2}$ were formed. It can thus be concluded that the improved retention of the lithium is responsible for the more stable behaviour exhibited by these catalysts. As reported previously for the $\mathrm{Li} / \mathrm{MgO}$ material, the $\mathrm{C}_{2}$ selectivity for those materials did not change while the yield decreased. We must therefore conclude that the decrease in yield is due to a drop in activity arising from a decrease with time of the number of active sites; there is apparently no appreciable change in the nature of these sites.

The loss of lithium in a fused $\mathrm{Al}_{2} \mathrm{O}_{3}$ reactor for the unpromoted and tin promoted samples was less then with materials tested in a quartz reactor. The main reason for the deactivation in these experiments is likely to be the formation of the volatile $\mathrm{LiOH}$. Although there was no evidence for the formation of a compound between lithium and the added tin, the tin seems to interact with the lithium in some way; this was discussed above in relation to analyses after calcination.

$\mathrm{The} \mathrm{Li} / \mathrm{Co} / \mathrm{MgO}$ (b) catalyst also gave an improved stability when compared with $\mathrm{Li} / \mathrm{MgO}$. However, with lithium depletion, the $\mathrm{C}_{2}$ yield and the $\mathrm{C}_{2}$ selectivity decreased. The decrease in $\mathrm{C}_{2}$ selectivity supports the argument, presented earlier, that lithium is mobile on the surface.

A tentative explanation for the increased stability of the doped $\mathrm{Li} / \mathrm{MgO}$ catalysts is possibly the increased interaction of oxygen with the catalyst. This may lead to a faster reoxidation of the catalyst and thus in a shorter residence time of the volatile $\mathrm{LiOH}$ on the surface of the catalyst.

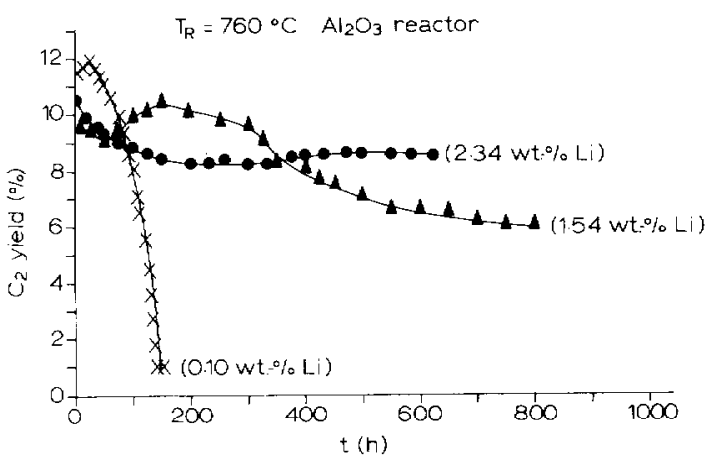

Fig. 8. The $\mathrm{C}_{2}$ yield as a function of time on stream at $T_{\mathrm{R}}=760^{\circ} \mathrm{C}$ in an alumina reactor for $\mathrm{Li} /$ $\mathrm{MgO}(\times), \mathrm{Li} / \mathrm{Sn} / \mathrm{MgO}(\mathrm{a})(\mathbf{A})$ and (b) ( $)$. 


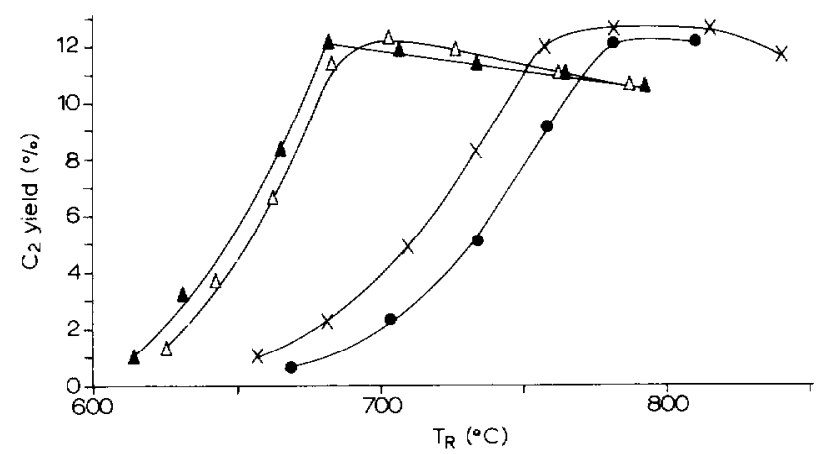

Fig. 9. The effect of addition of carbon dioxide to the reaction feed for $\mathrm{Li} / \mathrm{MgO}(\times), \mathrm{LiMgO}$ $\left(1.40 \% \mathrm{CO}_{2}\right)(\odot)$ and $\mathrm{Li} / \mathrm{Sn} / \mathrm{MgO}(\mathrm{b})(\Delta), \mathrm{Li} / \mathrm{Sn} / \mathrm{MgO}(\mathrm{b})\left(1.39 \%\left(\mathrm{O}_{2}\right)(\triangle)\right.$.

\section{Addition of carbon dioxide to the reaction feed}

In a recent paper [5] we have shown that the presence of carbon dioxide in the gas feed has two effects, namely to poison reversibly the active sites for the oxidative coupling reaction and also to stabilise them against deactivation. Fig. 9 shows the effect of the addition of carbon dioxide on the behaviour of the $\mathrm{Li}$ / $\mathrm{Sn} / \mathrm{MgO}$ catalyst (b) as a function of temperature compared with the behaviour without carbon dioxide addition and equivalent results for the $\mathrm{Li} / \mathrm{MgO}$ material under the same conditions. The addition of carbon dioxide has a slight poisoning effect, causing a slight decrease in the yield (without changing the selectivity) at any temperature; the effect is to shift the curve to slightly higher temperatures without changing the shape of the curve. The differences found for the unpromoted materials are substantially higher.

We have previously examined the kinetics of the methane-oxygen reaction over $\mathrm{Li} / \mathrm{MgO}$ and the effect on these of the addition of carbon dioxide to the reaction mixture; we came to the conclusion that the carbon dioxide competes with the oxygen and possibly also with the methane for the active sites and that the former is more strongly adsorbed [3]. Kinetic measurements with the $\mathrm{Li} / \mathrm{Sn} / \mathrm{MgO}$ catalyst have shown that the oxygen and the methane participating in the rate-determining step are more strongly adsorbed than on the unpromoted material [20]; we suggest that the lesser effect of carbon dioxide shown in Fig. 9 for the promoted material may therefore arise from the fact that the carbon dioxide competes less effectively with the more strongly bonded oxygen and methane present on this catalyst.

\section{CONCLUSIONS}

It is possible to improve the activity and stability of $\mathrm{Li} / \mathrm{MgO}$ catalysts by the addition of small amounts of various oxides. For a number of these oxides, 
this has little or no influence on the $\mathrm{C}_{2}$ selectivity of the resultant catalyst $\left(\mathrm{SnO}_{2}, \mathrm{Dy}_{2} \mathrm{O}_{3}, \mathrm{TiO}_{2}, \mathrm{~Tb}_{4} \mathrm{O}_{7}\right)$. It is possible that the added oxide can deliver active oxygen species which aid the methane coupling reaction.

Mobile $\mathrm{Li}_{2} \mathrm{CO}_{3}$ species probably exist on the catalyst surface, these having two functions:

(i) they inhibit total oxidation by preventing strong oxygen adsorption on the added promoter oxide; and

(ii) in the presence of oxygen, they allow the creation of active sites on the surface by the gradual loss of carbon dioxide from surface lithium carbonate species.

\section{ACKNOWLEDGEMENTS}

S.J.K. thanks the Dutch Foundation for Scientific Research for financial support. We also thank J.A. Vreeman for technical assistance and the NonNuclear Energy programme of the European Community for partial support of the work (Contract No. EN3C-039-NL(GDF)). Finally, we should also like to thank the Salt and Basic Chemicals Division of Akzo for a financial contribution.

\section{REFERENCES}

1 T. Ito and J.H. Lunsford, Nature (London), 314 (1985) 721.

2 T. Ito, J.-X. Wang, C.-H. Lin and J.H. Lunsford, J. Am. Chem. Soc., 107 (1985) 5062.

3 J.A. Roos, S.J. Korf, R.H.J. Veehof, J.G. van Ommen and J.R.H. Ross, Appl. Catal. 52 (1989) 147.

4 S.J. Korf, J.A. Roos, N.A. de Bruijn, J.G. van Ommen and J.R.H. Ross, J. Chem. Soc., Chem. Commun., (1987) 1433.

5 S.J. Korf, J.A. Roos, N.A. de Bruijn, J.G. van Ommen and J.R.H. Ross, Catal. Today, 2 (1988) 535.

6 S.J. Korf, J.A. Roos, J.M. Diphoorn, R.H.J. Veehof, J.G. van Ommen and J.R.H. Ross, Catal. Today, 4 (1989) 279.

7 M. Baerns, K. van der Wiele and J.R.H. Ross, Catal. Today, 4 (1989) 471.

8 K. Otsuka, K. Jinno and A. Morikawa, Chem. Lett., (1985) 499.

9 J.A. Roos, A.G. Bakker, H. Bosch, J.G. van Ommen and J.R.H. Ross, Catal. Today, 1 (1987) 133.

10 S.J. Korf, J.A. Rous, J.W.H.C. Derksen, J.A. Vreeman, J.G. van Ommen and J.R.H. Ross, in preparation.

11 J.A. Sofranko, J.J. Leonard and C.A. Jones, J. Catal., 103 (1987) 302.

12 R. Burch, G.D. Squire and S.C. Tsang, Appl. Catal., 46 (1989) 69.

13 F.P. Larkins and M.R. Nordin, in D.M. Bibby, C.D. Chang, R.F. Howe and S. Yurchak (Editors), Methane Conversion (Studies in Surface Science and Catalysis, Vol. 36), Elsevier, Amsterdam, 1988, p.409.

14 Bi Yingli, Zhen Kaiji, Jiang Yutao, Teng Chiwen and Yang Xiangguoung, Appl. Catal., 39 (1988) 185.

15 S. Bartsch, J. Falkowski and H. Hofmann, Catal. Today, 4 (1989) 421. 
16 J.A. Roos, S.J. Korf, R.H.J. Veehof, J.G. van Ommen and J.R.H. Ross, Catal. Today, 4 (1989) 441.

17 S.J. Korf, J.A. Roos, N.A. de Bruijn, J.G. van Ommen and J.R.H. Ross, Paper presented at the Bicentenary Catalysis Conference of the Royal Australian Chemical Institute, Sydney, September 1988, Appl. Catal., in press.

18 H.-S Zhang, J.-X Wang, D.J. Driscoll and J.H. Lunsford, J.Catal., 112 (1988) 366.

19 A. Bielanski and J. Haber, Catal. Rev. Sci. Eng., 19 (1979) 1.

20 S.J. Korf, J.A. Roos, J.A. Vreeman, J.W.H.C. Derksen, J.G. van Ommen and J.R.H. Ross, accepted for publication, Catalysis Today. 